\title{
EFEKTIVITAS PENGELOLAAN DANA DESA TERHADAP PEMBANGUNAN DAN PENINGKATAN EKONOMI MASYARAKAT PADA DESA MUSTIKA KECAMATAN KURANJI KABUPATEN TANAH BUMBU
}

\author{
I Wayan Wahyu Ananda \\ Sekolah Tinggi Ilmu Ekonomi Pancasetia \\ Jl. Ahmad Yani Km. 5.5 Banjarmasin \\ e-mail:wahyuananda2696@gmail.com
}

\begin{abstract}
The purpose of this study was to determine the effectiveness of village fund management on the development and improvement of the community economy in Mustika Village, Kuranji District, Tanah Bumbu Regency.

This research is a descriptive study with a quantitative approach, where this research focuses on the effectiveness of Village Fund management towards improving the economy of the community which has been in improving infrastructure, human resources, village-owned enterprises and household businesses carried out by the Mustika Village Government, Kuranji District, Tanah Bumbu Regency.
\end{abstract}

Keywords: Effectiveness of Village Fund Management

Abstrak: Tujuan dari penelitian ini adalah untuk mengetahui efektivias pengelolaan dana desa terhadap pembangunan dan peningkatan ekonomi masyarakat pada Desa Mustika Kecamatan Kuranji Kabupaten Tanah Bumbu.

Penelitian ini merupakan penelitian deskriptif dengan pendekatan kuantitatif, dimana penelitian ini berfokus pada efektivitas pengelolaan Dana Desa terhadap peningkatan ekonomi masyarakat yang selama ini dalam meningkatkan Infrastruktur, Sumberd Daya Manuasia, Badan Usaha Milik Desa dan Usaha Rumah Tangga dilakukan oleh Pemerintah Desa Mustika Kecamatan Kuranji Kabupaten Tanah Bumbu.

Kata Kunci : Efektivitas Pengelolaan Dana Desa. 


\section{Latar Belakang}

Guna mendukung pelaksanaan tugas dan fungsi desa dalam penyelenggaraan pemerintahan dan pembangunan desa dalam segala aspeknya sesuai dengan kewenangan yang dimiliki, UU Nomor 6 Tahun 2014 memberikan mandat kepada Pemerintah untuk mengalokasikan Dana Desa. Dana Desa tersebut dianggarkan setiap tahun dalam APBN yang diberikan kepada setiap desa sebagai salah satu sumber pendapatan desa. Kebijakan ini sekaligus mengintegrasikan dan mengoptimalkan seluruh skema pengalokasian anggaran dari Pemerintah kepada desa yang selama ini sudah ada.

Arah dan strategi kebijakan pembangunan desa dan perdesaan Pemerintah saat ini tidak bisa dilepaskan dari visi - misi Presiden untuk membangun Indonesia dari pinggiran dengan memperkuat daerah dan desa dalam kerangka NKRI. Upaya tersebut antara lain dilakukan dengan melalui pengalokasian Dana Desa yang lebih fokus pada pengentasan kemiskinan dan mengatasi ketimpangan antar desa.

Sejalan dengan sasaran pembangunan wilayah perdesaan dalam RPJMN 2015-2019, maka penggunaan dana desa perlu dirahkan untuk mendukung pengentasan desa tertinggal demi terwujudnya kemandirian desa. Penggunaan Dana Desa pada dasarnya merupakan hak Pemerintah Desa sesuai dengan kewenangan dan prioritas kebutuhan masyarakat desa setempat dengan tetap mengedepankan prinsip keadilan. Namun demikian, dalam rangka mengawal dan memastikan capaian sasaran pembangunan desa, Pemerintah menetapkan prioritas penggunaan dana desa setiap tahun.

Adapun data penerimaan dan laporan realisasi penggunaan dana desa pada Pemerintah Desa Mustika adalah sebagai berikut :
Tabel 1.1

\section{Pendapatan Desa 4 Tahun Terakhir}

(2015-2018)

\begin{tabular}{|c|l|c|c|c|c|}
\hline No & \multicolumn{1}{|c|}{ Pendapatan } & 2015 & 2016 & 2017 & 2018 \\
\hline 1. & Pendapatan Asli Desa & 0 & 0 & 0 & 0 \\
\hline 2. & Dana Desa & 274.157 .721 & 614.770 .333 & 781.101 .000 & 778.439 .000 \\
\hline 3. & Alokasi Dana Desa & 1.000 .000 .000 & 457.084 .476 & 521.227 .005 & 657.375 .537 \\
\hline 4. & Pendapatan lain-lain & 0 & 284.445 .191 & 0 & 1.781 .819 \\
\hline 5 & JUMLAH & 1.274 .157 .721 & 1.356 .300 .000 & 1.302 .328 .005 & 1.437 .596 .356 \\
\hline
\end{tabular}

Sumber : Pemerintah Desa Mustika.

Keterangan :

1. Pendapatan Asli Desa (PADes) merupakan pendapatan yang berasal dari kewenangan desa berdasarkan hak asal usul dan kewenangan skala lokal desa yang terdiri dari atas hasil usaha, hasil asset, swadaya dan partisipasi, gotong royong dan lain-lain pendapatan asli desa. Pada data yang terlihat bahwa Pemerintah Desa Mustika selama 4 (empat) tahun terakhir tidak menerima penghasilan asli desa.

2. Dana Desa adalah dana yang bersumber dari Anggaran Pendapatan Belanja Negara (APBN) yang diperuntukan bagi desa yang ditransfer melalui anggaran belanja daerah kabupaten/kota. Dimana data menunjukan dari tahun 2015-2018 Pemerintah Desa Mustika menerima dana desa dari tahun ketahun semakin besar sesuai dengan asal adil yaitu melihat dari jumlah penduduk, lokasi desa, potensi desa yang ada.

3. Alokasi Dana Desa (ADD) merupakan bagian keuangan desa yang diperoleh dari bagi hasil pajak daerah dan bagian dari dana daerah yang diterima oleh kabupaten/kota untuk desa yang dibagikan secara proporsional. Terlihat data menunjukan Pemerintah Desa Mustika menerima Alokasi Dana Desa setiap tahunnya dengan besaran yang 
berfariasi sesuai dengan pendapatan pemerintah daerah.

4. Pendapatan Lain-lain merupakan seluruh penerimaan desa yang sah dari sumbangan pihak ketiga yang tidak mengikat. Pada tahun 2016 Pemerintah Desa Mustika bantuan keuangan dari kabupaten/kota sedangkan pada tahun 2018 Pemerintah Desa Mustika menerima bantuan keuangan dari hasil mengikuti lomba desa ditahun 2017.

Tabel 1.2

\section{Laporan Realisasi Penggunaan Desa}

Desa 4 Tahun Terakhir (2015-2018)

\begin{tabular}{|c|l|c|c|c|c|}
\hline No & \multicolumn{1}{|c|}{ Bidang } & 2015 & 2016 & 2017 & 2018 \\
\hline 1. & $\begin{array}{l}\text { Penyelengaraan Pemerintah } \\
\text { Desa }\end{array}$ & 0 & 0 & 0 & 0 \\
\hline 2. & $\begin{array}{l}\text { Pelaksanaan Pembangunan } \\
\text { Desa }\end{array}$ & 264.157 .721 & 614.770 .333 & 762.101 .000 & 767.939 .000 \\
\hline 3. & Pembinaan Masyarakat & 0 & 0 & 0 & 0 \\
\hline 4. & Pemberdayaan Masyarakat & 10.000 .000 & 0 & 16.700 .000 & 0 \\
\hline 5 & Belanja Tak Terduga & 0 & 0 & 0 & 0 \\
\hline 6 & \multicolumn{1}{|c|}{ JUMLAH } & 274.157 .721 & 614.770 .333 & 778.801 .000 & 767.939 .000 \\
\hline 7 & $\begin{array}{l}\text { Sisa Lebih/Kurang Anggaran } \\
\text { Tahun Berjalan }\end{array}$ & 0 & 0 & 2.300 .000 & 0 \\
\hline
\end{tabular}

Sumber : Pemerintah Desa Mustika.

Berdasarkan laporan pendapatan dan realisasi anggaran dana desa pada Pemerintah Desa Mustika Kecamatan Kuranji Kabupaten Tanah Bumbu ini belumlah dapat memberikan informasi yang lebih mendalam tentang bagaimana dana desa yang diterima oleh pemerintah Desa Mustika dari pemerintah pusat secara transparan tentang pengelolaan dana tersebut dalam penggunaannya untuk peningkatan pembangunan desa dan peningkatan ekonomi masyarakat desa. Dimana anggaran dana desa yang dialokasikan lebih berfokus pada bidang pelaksanaan pembangunan desa hingga dengan $95 \%$ dari pagu anggaran yang ada, sedangkan alokasi dana desa untuk kegiatan pemberdayaan masyarakat atau peningkatan masyarakat desa kurang lebih 5\% dari pagu anggaran dana desa yang dikelola oleh pihak Pemerintah Desa Mustika Kecamatan Kuranji Kabupaten Tanah Bumbu. Tentu ini tidak lepas dari hasil musyawarah tingkat desa yang dituangkan dalam dokumen Musrenbangdes setiap tahunnya kemudian menjadi acuan kepala desa dalam menyusun Rencana Kerja Pemerintah Desa pada tahun anggaran selanjutnya dalam pengalokasian pendapatan dan belanja desa, walaupun apa yang sudah dilaksanakan oleh pihak Pemerintah Desa Mustika Kecamatan Kuranji Kabupaten Tanah Bumbu merupakan bentuk aspirasi masyarakat desa tetapi ini masih belum sesuai harapan pemerintah pusat untuk pengalokasian dana desa berfokus pada prioritas penggunaan dana desa untuk percepatan pembangunan desa, mengurangi angka kemiskinan dan peningkatan ekonomi masyarakat

\section{Metode Penelitian}

Penelitian ini mengenai Efektivitas Pengelolaan Dana Desa terhadap pembangunan dan peningkatan ekonomi masyarakat pada Desa Mustika Kecamatan Kuranji Kabupaten Tanah Bumbu, penelitian ini merupakan penelitian deskriptif dengan pendekatan kuantitatif, dimana penelitian deskriptif adalah penelitian yang dirancang untuk menggambarkan subjek penelitian dengan cara yang akurat. Lebih sederhananya, penelitian deskriptif adalah semua tentang deskripsi subjek yang diteliti dalam studi tersebut, sedangkan kuantitatif adalah penelitian ilmiah yang sistematis terhadap bagian-bagian dan fenomena serta hubungan-hubungannya.

Populasi dalam penelitian ini adalah Aparatur Pemerintah Desa yang terdiri dari Kepala Desa, Sekretaris Desa, Bendahara Desa, Kasi Pembangunan, Kasi Pemerintahan kemudian ditambah dengan 
dari tokoh Agama, Tokoh Masyarakat Desa Mustika Kecamatan Kuranji Kabupaten Tanah Bumbu dengan data pendukung Laporan Realisasi Anggaran Pendapatan dan Belanja Desa Tahun Anggaran 2015 sampai dengan 2018 Pemerintah Desa Mustika Kecamatan Kuranji Kabupaten Tanah Bumbu. Sedangkan sampel dalam penelitian yang dilakukan ini adalah Tim Pelaksana Kegiatan pengelola dana desa dengan data pendukung Laporan Realisasi Penggunaan Dana Desa Pada Desa Mustika Kecamatan Kuranji Kabupaten Kabupaaten Tanah Bumbu Tahun Anggaran 2015 sampai dengan 2018.

\section{Hasil Penelitian Dan Pembahasan}

Fokus kajian dalam penelitian ini yaitu Efektivitas Pengelolaan Dana Desa terhadap pembangunan dan peningkatan ekonomi masyarakat pada Pemerintah Desa Mustika Kecamatan Kuranji kabupaten Tanah Bumbu. Data-data yang diperlukan dalam permasalahan diperoleh melalui wawacara dan observasi pada hasil pembangunan atau realisasi penggunaan dana desa yang sudah dilaksanakan. Indikator meliputi adanya keterlibatan perangkat desa dan peranan masyarakat dalam pembangunan pengelolaan dana desa dan pengecekan pembangunan yang memanfaatkan dana desa. Hasil kajian data dari berbagai sumber tersebut dipaparkan sebagai berikut :

1. Pengelolaan Dana Desa pada Pembangunan dan Peningkatan Ekonomi Masyarakat Selama ini Perencanaan Dana desa tahun 2015 sampai dengan tahun 2018 pada Pemerintah Desa Mustika Kecamatan Kuranji Kabupaten Tanah Bumbu prioritas penggunaan Dana Desa digunakan untuk infrastruktur pembangunan desa. Pengelolaan Dana Desa pada Pemerintah Desa Mustika
Kecamatan Kuranji Kabupaten Tanah Bumbu berdasarkan pada musyawarah BPD, keputusan Kepala Desa dan Lembaga Masyarakat Berdasarkan rapat tersebut lalu disortir kegiatan atau pembangunan desa yang menjadi prioritas kebutuhan masyarakat desa yang rusak dan perlu untuk segera dibangun. Dengan adanya Dana Desa sangat meringankan beban masyarakat untuk melakukan pembangunan infrastruktur desa dimana masyarakat dapat menikmati hasil dari bentuk wujud adanya Dana Desa. Adapun 4 (empat) aspek peningkatan ekonomi masyarakat desa selama ini pada Desa Mustika Kecamatan Kuranji Kabupaten Tanah Bumbu adalah sebagai berikut :

a. Infrastruktur

Dampak paling besar yang dapat dirasakan oleh masyarakat desa mustika maupun pemerintah Desa Mustika Kecamatan Kuranji Kabupaten Tanah Bumbu adalah Bidang Infrastruktur pembangunan. Dimana semenjak tahun 2015 sampai saat ini pengelolaan dana desa langsung dikelola oleh pemerintah desa stempat sehingga dapat memenuhi kebutuhan desa, masyarakat dalam mengentas ketertinggalan pembangunan infrastruktur maupun pengembangan sumber daya manusianya. Jika melihat data yang diperoleh dari Pemerintah Desa Mustika dengan keadaan dilapangan dimana prioritas penggunaan dana desa berfokus pada infrastruktur yang dirasa sangat mendasar menjadi program kerja pemerintah desa Mustika kecamatan Kuranji Kabupaten Tanah Bumbu seperti penin, · I kapasitas pembangunan jali ? 
dimana diketahui semenjak tahun pembukaan lahan transmigrasi sampai tahun 2014 program pembangunan dirasa belum maksimal baik dari sumber anggaran maupun sasaran pembangunannya. Dengan adanya dana desa yang diterima mulai tahun 2015 sampai dengan saat ini pemerintah Desa Mustika Kecamatan Kuranji Kabupaten Tanah Bumbu sangat memperhatikan kebutuhan masyarakatnya dimana saat ini pembangunan tembok penahan tanah dan pengerasan jalan desa sudah mencapai target sehingga tidak ada lagi jalan desa yang rusak maupun tidak layak dilewati. Disamping itu juga pembangunan plat duiker atau gorong-gorong dan jembatan telah telah selsai semua dikerjakan sehingga saat ini dengan jalan yang baik dan jempatan yang mumpuni masyarakat Desa Mustika banyak mengalami peningkatan dilihat dari mudahnya akses jalan desa dan jembatan yang memudahkan mereka untuk melakukan usaha tidak lagi terhambat oleh jalan yang rusak atau jembatan yang tidak dapat dilewati sehingga menghambat usaha dari masyarakat. Disamping itu pemerintah Desa Mustika Kecamatan Kuranji Kabupaten Tanah Bumbu juga memperhatikan masyarakakatnya yang mayoritas petani dengan membangun jalan usaha tani dan embung desa yang dapat membantu para petani untuk mudah mengakses jalan pertanian dan menyediakan cadangan air bersih untuk kebutuhan pertanian maupun memenuhi kebutuhan sehari-hari. b. Sumber Daya Manusia

Membandingkan data dari Pemerintah Desa Mustika Kecamatan Kuranji Kabupaten Tanah Bumbu dengan hasil wawancara bersama tim pelaksana pengelola dana desa didapat sesuai dengan petunjuk penggunaan dana desa bahwa selama ini sebagian kecil dari pagu dana desa diperuntukan pengembangan sumberdaya manusia. Dapat dilihat dari laporan setiap tahunnya ada pelatihan-pelatihan yang diadakan oleh pihak Pemerintah Kabupaten/Kota mulai dari pelatihan kepala desa dan perangkat desa, BPD dan lembaga masyrakat serta pelatihan bagi industri rumahan seperti pemanfaatan teknologi tepat guna. Walaupun saat ini belum mencapai hasil maksimal yang diharpakan mengingat prioritas penggunaan dana desa lebih tertuju pada infrastruktur pembangunan desa. Lebih jelas lagi selama ini pemberian pelatihan tersebut masih dtujukan kepada pengelola keuangan dana desa dan penatausahaan keuangan desa, hanya sebagian kecil saja atau baru sedikit sekali kegiatan pelatihan yang diberikan untuk peningkatan sumber daya manusia pada masyarakar mengingat potensi masyarakat Desa Mustika cukup banyak mengingat masyarakatnya merupakan transmigran dari pulau jawa dan bali tentunya masih memegang erat seni dan kebudayaan daerah asalnya yang harus dikembangkan lagi 
disini. Hal ini terus dilakukan agar tidak hanya infrastruktur desa saja yang dibangun melainkan sumber daya manusia masyrakat desa setempat juga dibangun dipersiapkan untuk mendukung meningkatkan pendapatan perkapita masyarakat desa, meningkatnya pendapatan desa dan mempercepat kemajuan desa.

c. Badan Usaha Milik Desa (BUMDes)

Pengelolaan Dana Desa pada Pemerintah Desa Mustika Kecamatan Kuranji Kabupaten Tanah Bumbu sudah cukup baik. semua Dana Desa Tahun 2015 sampai dengan tahun 2018 digunakan untuk pembangunan yang $t$ dinikmati langsung oleh ....., khususnya untuk peningkatan ekonomi masyarakat desa dengan pengalokasian pembentukan dan penguatan modal Badan Usaha Milik Desa (BUMDes) Sengkuyung dengan unit usaha simpan pinjam dan pangkalan gas LPG 3 Kg. Yang mana jika dibandingkan dengan selama ini sebelum adanya dana desa atau BUMDes kini masyarakat desa dapat dibantu melalui unit simpan pinjam diharapkan dengan jumlah pinjaman tersebut dapat membantu usaha ataupun memenuhi kebutuhan msyarakatnya mengingat bunga yang diberikan oleh BUMDes sangatlah minim sehingga tidak memberatkan nasabah atau masyarakat sebagai peminjam. Selain itu dengan unit pangkalan LPG ini BUMdes sudah menjadi tidak terpisahkan dengan masyarakat, dengan ketersediaan LPG $3 \mathrm{Kg}$ dengan harga lebih murah dari pangkalan lain tentu ini juga menjadi jawaban atas kebutuhan masyarakat desa. Yang paling dirasakan dengan penggunaan dana desa dialokasikan untuk pembenukan dan penguatan modal BUMDes tentu adanya peningkatan pendapatan masyakat yang dibantu oleh permodalan dari BUMDes, pemenuhan kebutuhan akan gas LPG murah, meningkatnya pendapatan alsi desa dari bagi hasil BUMDes menjadi sangat dirasakan pemanfaatan dana desa oleh masyarakat maupun Pemerintah Desa Mustika Kecamatan Kuranji Kabupaten Tanah Bumbu.

d. Usaha Rumah Tangga

Sudah disinggung pada pembahasan sebelumnya bahwa sebagian dari prioritas penggunaan dana desa diperuntukan peningkatan sumber daya manusia msayarakat, dimana tahapan tersebut akan dimulai dengan palatihan-pelatihan diikuti dengan pemberian modal melalui BUMDes sampai akhirnya masyarakat berkembang dengan membentuk usaha rumah tangga atau industry rumah tangga. Melihat dari angkat pagu dana desa yang setiap tahunnya mengalami peningkatan kegiatan 
pengembangan usaha rumah tangga ini belum berjalan secara maksimal. Hal ini disebakan bukan dari anggaran yang cukup ataupun masyarakatnya tidak memiliki kemauan tetapi kurangnya pelatihan yang mengarah pada peningkatan industry rumahan atau usaha rumah tangga. Ini menjadi tanggung jawab Pemerintah Desa Mustika Kecamatan Kuranji Kabupaten Tanah Bumbu tentunya dalam mengatasi permaslahan yang timbul selama ini agar nantinya program-program dari pemerintah pusat melalui pemerintah desa benar-benar terlaksna degan baik dan maksimal.

2. Pengelolaan Dana Desa pada Pembangunan dan Peningkatan Ekonomi Masyarakat yang seharusnya Hasil penelitian menunjukan bahwa Pengelolaan Dana Desa pada Pemerintah Desa Mustika Kecamatan Kuranji Kabupaten Tanah Bumbu terbilang sudah baik dimana seluruh pengelolaan Dana Desa berpedoman pada peraturan-peraturan yang mengatur pengelolaan Dana Desa tersebut. Namun masih ada banyak hal yang perlu diperbaiki dalam pengelolaan Dana Desa pada Pemerintah Desa Mustika sesuai dengan Peraturan Menteri Desa Pembangunan Daerah Tertinggal dan Transmigrasi Republik Indonesia Nomor 19 Tahun 2017 Tentang Prioritas Penggunaan Dana Desa Tahun 2018 diantaranya :

\section{a. Infrastruktur}

Melihat pesatnya bembangunan mulai pada tahun 2015 sampai saat ini melalui anggaran dana desa tentu ini merupakan sebuah catatan keberhasilan pemerintah pusat, pemerintah daerah amupun Pemerintah Desa Mustika Kecamatan Kuranji Kabupaten Tanah Bumbu saat ini benar-benar dirasakan manfaatnya dana desa mulai dari jalan desa, jalan usaha tani, jembatatn hingga embung desa. Tetapi dibalik keberhasilan tersebut tentu masih ada beberapa hal yang harus diperhatikan kembali oleh pengelola dana desa dalam hal ini adalah Pemerintah Desa Mustika Kecamatan Kuranji Kabupaten Tanah Bumbu. Terutama padapembangunan penunjang proses produksi hasil tani masyrakat seperti pembangunan jalan usaha tani yang dirasa masih belum cukup dimana masih ada beberapa titik jalan usaha tani yang masih rusak sehingga tidak dapat di aksek oleh kendaraan roda empat. Disamping itu perlu adanya penambahan bebrapa titik embung yang berada didaerah pertanian sehingga petani tidak kekurangan cadangan air untuk pengairan dan pengoptimalan embung desa yang sudah terbangun dengan pencucian embung desa, penambahan kedalaman embung sampai dengan siring permanen pada embung desa sehingga nantinya embung ini selain mampu memenuhi kebutuhan pertanian juga mampu memenuhi kebutuhan air bersih sehari-hari walaupun musim kemarau berkepanjangan dating. Perlu juga adanya perhatian kepada gedunggedung yang sudah tidak layak digunakan agar dapat dilaksanakan perbaikan atau 
bahkan pembangunan gedung baru, sebagai contoh gedung serbagunan yang sudah termakan usia atap mulai banyak yang bocor dan bangunan sudah mulai terlihat miring. Untuk peningkatan keamanan desa perlu adanya pembangunan pos kamling permanen pada setiap RT dan disertai penerangan jalan desa yang saat ini masih kurang memadai. Ini bertujuan untuk memberikan rasa aman dan nyaman kepada masyarakat nantinya saat melakukan usaha.

b. Sumber Daya Manusia

Pada pembahasan ini pengelolaan dana desa yang telah diterima oleh Pemerintah Desa Mustika Kecamatan Kuranji Kabupaten Tanah Bumbu selama ini baru menyentuh sedikit dari target capaian yang diharapkan. Selain minimnya anggaran yang dialokasikan untuk kegiatan pelatihan-pelatihan untuk pengembangan sumber daya manusia pada masyarakat desa tatapi juga dikarenakan petunjuk atau dasar hukum unuk menganggarkan kegiatan tersebut masih belum disempurnakan, sehinggaa pengelola dana desa dalam hal ini pemerintah Desa Mustika Kecamatan Kuranji Kabupaten Tanah Bumbu tidak dapat memaksimalkan anggaran untuk kegiatan tersebut. Ini menjadi perhatian bagi pihak pengelola dana desa dimana seharusnya dengan adanya dana desa ini mampu mengali potensi masyarat Desa Mustika, dimana diketahui masyarakat $n$ Mustika mayoritas trar jawa dan bali yang memegang erat budaya dan tradisi daerah asalnya, maka pemerintah desa mustika selain dapat memaksimalkan pelatihanpelatihan untuk peningkatan industri rumahan juga dapat melaksanakan pelatihan untuk mendatangkan pelatih atau pengerajin bali atau jawa untuk melatih masyarakat desa mustika dimana tujuannya adalah menciptakan kerajinan atau hasil seni bercorak bali atau jawa dari Desa Mustika kecamatan Kuranji Kabupaten Tanah Bumbu yang memiliki nilai jual tinggi yang mampu bersaing dipasaran.

c. Badan Usaha Milik Desa (BUMDes)

Dengan adanya Dana Desa kegiatan pembangunan pada pemerintah Desa Mustika kecamatan Kuranji Kabupaten Tanah Bumbu tidak lagai monoton pada bidang pembangunan infrastruktur desa yang sama rata dan sama rasa, tetapi mulai memperhatikan potensi-potensi yang ada di desa dan masyarakat desanya. Sebagai salah satu bentuk pengembangan Dana Desa yang sudah diterima mulai sejak tahun 2015 dengan berdirinya Badan Usaha Milik Desa (BUMDes) Sengkuyung yang bergerak dibidang simpan pinjam dan pangkalan gas LPG $3 \mathrm{Kg}$ lebih diperhatikan dan ditingkatkan. Mengingat dimana unit usaha simpan pinjam berbeda dengan unit usaha pangkalan gas LPG yang sudah memiliki badan hukum yang sah, unit usaha simpan pinjam BUMDes Sengkuyung masih belum memiliki payung hukum yang 
dikhawatirkan dimana unit usaha ini dengan jumlah modal dan hasil yang tidak sedikit dikemudian hari terjadi sesuatu hal yang tidak diinginkan. Melihat potensi letak Desa Mustika Kecamatan Kuranji Kabupaten Tanah Bumbu yang terletak diantara perusahaan kelapa sawit dan perushaan pertambangan, BUMDes salah satu sumber pendapatan desa mampu mengelola CSR dari kedua perusahaan tersebut yang semenjak berdirinya perusahaan di lingkungan desa belum memberikan CSR kepada Pemerintah Desa Mustika Kecamatan Kuranji Kabupaten Tanah Bumbu. Seharusnya dengan adanya BUMDes dan Dana Desa ini mampu menjadi jembatan untuk pemerintah mengoptimalkan hasil pendapatan desa.

Melihat dari mayoritas penduduk desa pada Desa Mustika Kecamatan Kuranji Kabupaten Tanah Bumbu sebagian besar sebagai petani karet, petani padi dan petani sawit dengan pengelolaan Dana Desa oleh langsung dari Pemerintah Desa Mustika Kecamatan Kuranji Kabupaten Tanah Bumbu pada tahun berikutnya juga dapat lebih memperhatikan jalan usaha tani guna memudahkan transportasi dan mobilisasi masyarakat yang saat ini masih terbilang belum cukup baik. BUMDes juga dapat ambil andil dengan membentuk unit usaha baru yang menyediakan kebutuhan alat dan bahan pertanian yang masih susah didapatkan dengan harga lebih murah, selain membantu para petani dalam memenuhi kebutuhannya dari unit usaha ini juga bisa menambah usaha BUMDes sebagai salah satu pendapatan desa yang mana nantinya diharapakan mampu membantu mensejahterakan masyarakat khususnya Desa Mustika Kecamatan Kuranji Kabupaten Tanah Bumbu.

d. Usaha Rumah Tangga

Melihat data yang diterima bahwa belum maksimalnya pengelolaan dana desa sehingga searusnya perlu perhatian khusus dalam pengelolaan dana desa agar tepat sasaran khusunya dalam peningkatan ekonomi masyarakat melalui usaha rumah tangga atau industri rumahan. Melihat potensi sumberdaya alamnya melalui sumber pertanian yang dapat diolah menjadi bahan makanan yang memiliki nilai jual seperti hasil perkebunan singkı ubi-ubian, pisang dan bal pertanian lainnya. Ini perlu perhatian dan pendampingan dari pemerintah Desa Mustika Kecamatan Kuranji Kaubupaten Tanah Bumbu dengan mengadakan atau mendatangkan pelatih pengelola sumber daya alam hasil perkebunan tersebut dan perlu juga adanya pengadaan alat pres atau alat pengemasan agar selain hasilnya menjadi maksimal juga memiliki kemasan yang bagus untuk dapat bersaing dengan produk olahan industri di pasaran. Hal ini dimaksudkan nantinya melalui dana desa yang diterima oleh Pemerintah Desa Mustika Kecamatan Kuranii Kabupaten Tanah Bumbı rasakan secara lagsung 


manfaatnya dibidang peningkatan
ekonomi masyarakat dapat
menjadi masyarakat yang
mandiri, memiliki pendapatan
tambahan dari hasil usaha
rumahan dibantu didampingi oleh
pemerintah desa sehingga tercipta
hubungan baik antara pendapatan
perkapita kepada pendapatan desa
nantinya menuju desa yang
mandiri, maju dan berkembang
dibidang perekonomiannya
sehingga tidak memiliki
ketergantungan terhadap dana-
dana yang dikeluarkan oleh
pemerintah pusat maupun
pemerintah daerah
kabupaten/kota.

\section{Kesimpulan}

Berdasarkan hasil penelitian yang telah dilakukan maka dapat di tarik kesimpulan bahwa Efektivitas Pengelolaan Dana Desa Terhadap Pembanguna dan Peningkatan Ekonomi Masyarakat pada Pemerintah Desa Mustika Kecamatan Kuranji Kabupaten Tanah Bumbu diperoleh kesimpulan sebagai berikut :

1. Mengacu pada data yang diterima Pemerintah Desa Mustika Kecamatan Kuranji Kabupaten Tanah Bumbu dan hasil penelitian Tahun Anggaran 2015-2018 menunjukan pengelolaan Dana Desa selama ini yang dilakukan oleh Pemerintah Desa Mustika Kecamatan Kuranji Kabupaten Tanah Bumbu terbilang sudah baik dapat dilihat dari pengelolaan keuangannya desa selalu berpedoman pada peraturan-peraturan yang mengatur dana-dana yang diterima oleh desa dari pemerintah pusat maupun pemerintah daerah. Dalam pengambilan keputusan mengenai perencanaan pengalokasian Dana Desa selalu dibicarakan dalam forum musyawarah desa yang hasil dari musyawarah tersebut menjadi bahan atau pedoman menyusun rencana kerja pemerintah desa sesuai dengan siklus pengelolaan dana desa menurut Peraturan Menteri Dalam Negeri Nomor 6 Tahun 2014 Tentang Desa. Tahap perencanaan Dana Desa (DD) desa telah menerapkan prinsip partisipasi dan transparansi. Hal ini dibuktikan dengan dicapainya 4 (empat) aspek efektivitas pengelolaan dana desa baik itu dari aspek infrastruktur, sumber daya manusia,BUMDes dan usaha rumah tangga yang dapat dirasakan langsung oleh masyarakat Desa Mustika walaupun masih ada beberapa aspek yang perlu perhatian khusus dan pemaksimalan dalam pengelolaan kegiatannya.

2. Hasil Penelitian Pada Pemerintah Desa Mustika Kecamatan Kuranji Kabupaten Tanah Bumbu telah menerapkan prinsip transparansi dan akuntabilitas. Prinsip transparansi terpenuhi dengan adanya informasi yang jelas mengenai jadwal pelaksanaan fisik yang di danai oleh Dana Desa. Untuk prinsip akuntabilitas sudah terlaksana sepenuhnya karena pertanggungjawaban secara fisik dan administrasinya sudah selesai dan lengkap. Dalam pelaksanaan prioritas penggunaan Dana Desa (DD) pada Pemerintah Desa Mustika Kecamatan Kuranji Kabupaten Tanah Bumbu harus lebih berfokus pada pengembangan prioritas penggunaan Dana Desa sesuai dengan Peraturan Menteri Desa Nomor 19 Tahun 2017 Tentang Prioritas Penggunana Dana 
Desa Tahun 2018 yang dimana Pemerintah Desa Mustika Kecamtan Kuranji Kabupaten Tanah Bumbu dengan memperhatikan kembali bagaimana seharusnya dana desa ini dikelola untuk lebih memperhatikan aspek lainnya selain dari aspek infrastruktur pembangunan desa yaitu peningkatan ekonomi masyarkat desa. Dimulai dari pemanfaatan dana desa dialokasikan untuk peningkatakan modal BUMDes, kemudian didukung dengan pengembangan sumber daya manusia dan peningkatan usaha rumah tangga. Dimana aspek-aspek ini akan memiliki kesinambungan dengan saling keterkaitan yang dimulai dari menggali potensi desa melaui BUMDes, mengelola program CSR dari perusahaan yang ada diarea Desa Mustika yang nantinya dikembangkan lagi menjadi pendapatan asli desa yang akan disalurkan kemasyarakat desa mengingat dana desa terbatas oleh aturan yang mengatur penggunaan dana desa sehingga saat ini perlu penguatan modal BUMDes yang nantinya akan menjadi sumber pendapatan asli desa sehingga terwujudnya desa yang mandiri, maju dan berkembang.

\section{DAFTAR PUSTAKA}

Elsa Dwi Wahyu Dewanti, 2015, Analisis Perencanaan Pengelolaan Keuangan Desa,Fakultas Ekonomi, Universitas Jember.

Keputusan Bersama, Menteri Dalam Negeri, Menteri Keuangan, Menteri Desa, Pembangunan Daerah Tertinggal dan Transmigrasi dan Menteri Perencanaan Pembangunan Nasional/Kepala Badan Perencanaan Pembangunan Nasional, Nomor 1408698 Tahun 2017, Nomor 954/KMK.07/2017, Nomor 116 Tahun 2017, Nomor 01/SKB/M.PPN/12/2017, Tentang
Penyelarasan dan Penguatan Kebijakan Percepatan Pelaksanaan Undang-undang Nomor 6 Tahun 2014 Tentang Desa.

Nuruk Riyani, 2016, Analisis Pengelolaan Dana Desa,Fakultas Keguruan dan Ilmu Pendidikan, Universitas Muhammadiyah Surakarta.

Peraturan Menteri Desa Nomor 19 Tahun 2017 Tentang Prioritas Penggunana Dana Desa Tahun 2018.

Peraturan Menteri Dalam Negeri Nomor 113 Tahun 2014 tentang Pengelolaan Keuangan Desa

Peraturan Menteri Dalam Negeri Nomor 114 Tahun 2014 tentang Pedoman Pembangunan Desa.

Peraturan Menteri Keuangan Republik Indonesia Nomor 49 /PMK/.07/2016 Tentang Tata Cara Pengalokasian, Penyaluran, Penggunaan, Pemantauan dan Evaluasi Dana Desa.

Peraturan Menteri Keuangan Nomor 49 Tahun 2016 tentang cara pengelolaan, penyaluran, penggunaan, pemantauan, dan evaluasi Dana Desa.

Rencana Pembangunan Jangka Menengah Desa (RPJMDes) Pemerintah Desa Mustika Nomor 01 Tahun 2014.

Rencana Kerja Pemerintah Desa (RKPDes) Pemerintah Desa Mustika Nomor 4 tahun 2015 Tentang Rencana Kerja Pemerintah Desa Tahun 2016

Rencana Kerja Pemerintah Desa (RKPDes) Pemerintah Desa Mustika Nomor 3 tahun 2016 Tentang Rencana Kerja Pemerintah Desa Tahun 2017.

Rencana Kerja Pemerintah Desa (RKPDes) Pemerintah Desa Mustika Nomor 2 tahun 2017 Tentang Rencana Kerja Pemerintah Desa Tahun 2018.

Savarita Pitri, 2018, Analisis Manajemen Dana Desa Terhadap Pembangunan Desa Dalam Perspektif Ekonomi Islam, Fakultas Ekonomi Dan Bisnis Islam, Universitas Islam Negeri Raden Intan Lampung.

Sri Lestari, 2017, Analisis Akuntabilitas Pengelolaan Aloksi Dana Desa (ADD),Fakultas Ekonomi dan Bisnis Islam, Institut Agama Islam Negeri Surakarta. 
43 Kindai, Vol 17, Nomor 1, Halaman 032-043

Undang-Undang Nomor 6 Tahun 2014 tentang Desa. 